Available online at http://jurnal.goretanpena.com/index.php/JSSR

\title{
PERSEPSI MAHASISWA TENTANG IMPLEMENTASI BLENDED LEARNING DI UNIVERSITAS MUHAMMADIYAH BENGKULU
}

\author{
Rio Saputra ${ }^{1}$, Rina Yuniarti ${ }^{2}$, Gunawan ${ }^{3}$ \\ ${ }^{1}$ Pendidikan Bahasa dan Sastra Indonesia, Universitas Muhammadiyah Bengkulu \\ ${ }^{2}$ Akuntansi, Universitas Muhamamdiyah Bengkulu \\ ${ }^{3}$ Sistem Informasi, Universitas Muhamamdiyah Bengkulu \\ Email: ${ }^{1}$ riosaputra@umb.ac.id, ${ }^{2}$ rinayuniarti@umb.ac.id, ${ }^{3}$ gunawan@umb.ac.id
}

\begin{abstract}
The implementation of Blended learning has only been implemented in the last year at the University of Muhammadiyah Bengkulu. The use of this learning model needs to be evaluated for its implementation to improve the quality of learning on an ongoing basis. Students' perceptions as users of blended learning are important to improve the system and use blended learning. The purpose of the study was to describe students' perceptions of the implementation of blended learning at the University of Muhammadiyah Bengkulu. This research is a quantitative survey research. The research sample was 1,204 students at the University of Muhammadiyah Bengkulu from various study programs. Data collection techniques using a questionnaire. Data were analyzed using quantitative descriptive. The results of the study are (1). Students prefer to use the online learning model using the kito class compared to other learning models, such as zoom, google meet, whatsapp call (2). Students can learn in a comfortable environment, at their own pace and can learn repeatedly, (4) there are 856 students who think that our class is better than other methods, (5) a small number of 348 students think that they feel bored and find it difficult to learn. learn through our class.
\end{abstract}

Keyword: perception; blended learning

Abstrak: Implementasi Blended learning baru diterapkan satu tahun terakhir di Universitas Muhamamdiyah Bengkulu. Pemanfaatan model pembelajaran ini perlu dievaluasi pelaksanaannya untuk melakukan peningkatan kualitas pembelajaran secara berkelanjutan. Persepsi Mahasiswa sebagai pengguna blended learning menjadi penting untuk melakukan perbaikan sistem dan pemanfaatan blended learning. Tujuan penelitian untuk mendeskripsikan persepsi mahasiswa tentang implementasi blended learning di Universitas Muhammadiyah Bengkulu. Penelitian ini adalah penelitian kuantitatif survey. Sampel penelitian adalah mahasiswa di Universitas Muhammadiyah Bengkulu sebanyak 1.204 dari berbagai program studi. Teknik pengumpulan data menggunakan kuesioner. Data dianalisis menggunakan deskriptif kuantitatif. Hasil penelitian yaitu (1). Mahasiswa lebih suka menggunakan model pembelajaran daring menggunakan kelas kito dibandingkan model pembelajaran yang lain, seperti zoom, google meet, whatapss call (2). Mahasiswa dapat belajar di lingkungan yang nyaman, sesuai dengan kecepatan mereka sendiri dan dapat belajar berulang kali, (4) terdapat 856mahasiswa berpendapat bahwa kelas kito lebih baik daripada metode lain,(5) sebagian kecil 348mahasiswa berpendapat bahwa mereka merasa bosan dan sulit untuk belajar melalui kelas kito.

Kata kunci: persepsi;blended learning

\section{PENDAHULUAN}

Perkembangan

teknologi seharusnya menjadi peluang besar dalam mendukung pembelajaran yang efektif dan produktif ditandai dengan era digital. Era digital dalam pendidikan mengharuskan pembelajaran yang berpusat pada peserta didik, komunikasi interaktif, kemandirian, dan pendidik sebagai fasilitator.Olehkarena itu, era digitalisasi pendidikan menuntut adanya inovasi, salah satunya blended learning.Blended learning sebenarnya telah lama dikembangkan sebagai suatu 
Available online at http://jurnal.goretanpena.com/index.php/JSSR

model pembelajaran, namun di Indonesia realatif baru dikenal karena berbagai faktor.

Blended learning adalah kombinasi instruksi dari pembelajaran online dan pembelajaran tatap muka untuk membantu mengembangkan pengetahuan dan keterampilan baru (Porter et al., 2014; Hilliard, 2015). Blended learning terjadi ketika ada kesempatan peserta didik berdiskusi dalam forum asinkron kemudian pendidik menjelaskan secara langsung/sinkron atau konferensi video, dan ketika kuliah atau kegiatan pelatihan diadakan secara virtual daripada tatap muka (Bonk \& Kim, 2004). Oleh karena itu, menurut Stockwell et al., (2015) blended learning merupakan paradigma yang muncul dalam pendidikan sains tetapi tidak menggunakan penilaian yang kaku.Porter etal. (2014)bahwa tujuan utama universitas menerapkan blended learning adalah untuk mengembangkan pedagogi.

Manfaat dari blended learning adalah temporal dan atau mempertimbangkan akses geografis dan fleksibilitas, maka universitas juga menyebutkan bahwa blended learning memiliki biaya yang efektif (Porter et al., 2014). Dalam blended learning, potensi peserta didik sangat dibutuhkan terutama kemandirian belajar mereka. Kegunaan lain dari blended learning adalah untuk meningkatkan kemampuanpeserta didik dalam membangun pengetahuan, serta kemampuan untuk menilai dan mengevaluasi sehingga akan menghasilkan peserta didik yang terampil yang dapat menjadi lulusan inovatif yang mampu memenuhi kebutuhan kerja melalui kreativitas dan inovasi mereka (Kintu et al., 2017; Septiana, 2020).

Universitas Muhammadiyah Bengkulu memiliki program e-learning yang disebut Kelas Kito. Kelas Kito sebagai salah satu sarana untuk melakukan blended learning.
Penggunaan blended learning dalam kuliah ini adalah kombinasi dari pembelajaran online menggunakan Kelas Kito dan pembelajaran tatap muka di kelas. Pembelajaran onlinedengan Kelas Kito berisi materi pembelajaran dalam bentuk modul dan slide PowerPoint, artikel dari jurnal, video pembelajaran, forum diskusi, kuis, tugas, dan latihan. Dengan demikian, mahasiswa dapat belajar secara mandiri secara online. Pembelajaran tatap muka berisi penyampaian materi, latihan, dan praktik melakukan simulasi pembelajaran mata kuliah menggunakan berbagai strategi pembelajaran. Implementasi blended learning untuk semua mata kuliah ini adalah 1 semester. Desain instruksional dalam blended learning dimulai dengan mendesain ulang rencana pelajaran dan menulis ringkasan kuliah. Materi pembelajaran yang disiapkan yaitu untuk kegiatan tatap muka dengan $e$ learning. Sumber dan bahan pembelajaran dikembangkan sesuai dengan tujuan pembelajaran maka kegiatan review yang berkelanjutan sangat dibutuhkan (Cheung et al., 2010; Septiana, 2020). Pentingnya dilakukan penelitian ini adalah untuk mengeksplorasi persepsi mahasiswa tentang Blended Learning dalam mata kuliah, kemudian hasil penelitian ini untuk memberikan masukan atau saran implementasi blended learning ke depannya. Tujuan penelitian ini adalah untuk menggambarkan persepsi mahasiswa tentang implementasi blended learningdi Universitas Muhammadiyah Bengkulu.

\section{METODE}

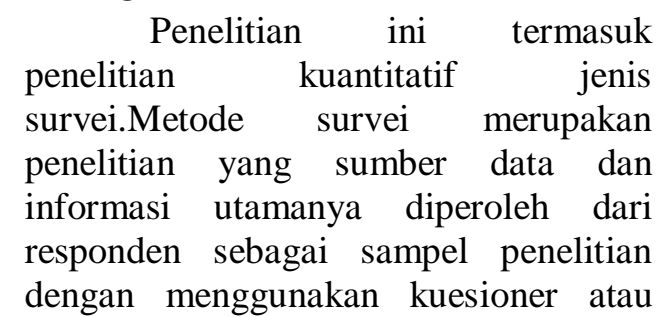


Available online at http://jurnal.goretanpena.com/index.php/JSSR

angket sebagai instrumen pengumpulan data. Data diperoleh dengan membagikan Angket kepada para mahasiswa yang menjalankan proses belajar mengajar dengan metode daring selama pandemiCovid-19. Mahasiswa diminta kesediannya untuk mengisi kuesioner yang sudah dibagikan secara daring dengan Link Google Form (https://bit.ly/3ivNbNW) melalui Gugus Penjamin Mutu masing-masing fakultas, sebagai monitoring dan evaluasi yang dilakukan oleh Lembaga Penjamin Mutu dan Pengembangan Pendidikan (LPMPP) Universitas Muhammadiyah Bengkulu yang dilakukan di akhir semester pembelajaran. Mahasiswa wajib login menggunaka email sebagai langkah untuk memverifikasi respons yang masuk. Keseluruhan metode yang digunakan dalam penelitian ini ditampilkan pada gambar 1 di bawah ini

\section{Method}

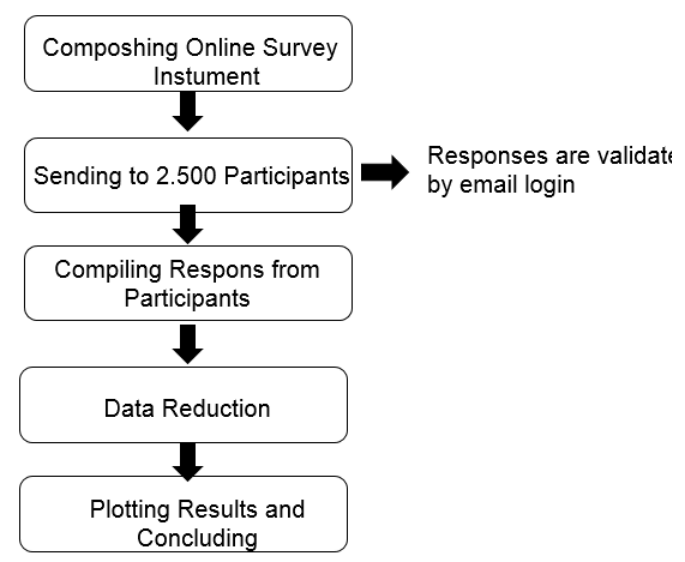

Gambar 1. Metode penelitian

Penelitian ini menggunakan populasi mahasiswa Universitas Muhammadiyah Bengkulu. Sampel pada penelitian ini 1.204terdiri dari semua program studi yang ada di Universitas Muhammadiyah Bengkulu. Teknik pengumpulan data yang digunakan adalah kuisioner dengan skala Likert dengan tujuan untuk mengukur persepsi mahasiswa terhadap pembelajaran daring. Mahasiswa menentukan tingkat persetujuannya dengan memilih salah satu pilihan yang tersedia. Format kuisioner yang diberikan kepada mahasiswa disediakan dengan empat skala sebagai berikut: 1. Sangat Setuju (SS); 2. Setuju (S); 3. Tidak Setuju (TS); 4. Sangat Tidak Setuju (SST). Kuisioner ini juga terdiri dari 16 pernyataan. Kuisioner yang diberikan kepada respondenmenggunakan kuesioner. Kuesioner penelitian ini mengadaptasi kuesioner dari penelitian yang dilakukan oleh Akkoyunlu \& Yilmaz-Soylu (2008). Teknik analisis data dalam penelitian ini dilakukan dengan mereduksi data, menyajikan data dan menarik kesimpulan.

\section{HASIL DAN PEMBAHASAN}

Penelitian dilakukan kepada mahasiswa aktif yang melaksanakan pembelajaran di semester genap tahun akademik 2019/2020 yaitu semua mahasiswa Universitas Muhammadiyah Bengkulu jumlah 2500 orang. Namun responden yang telah mengisi form berjumlah 1.204 orang. Adapun sebaran responden terdiri dari 26,8\% dari mahasiswa Fakultas Ekonomi, 26,3\% mahasiswa Fakultas Pertanian, 15,7\% dari mahasiswa FISIP, dan sisanya dari mahasiswa FKIP, FAI, Fakultas Teknik, FIKES dan Fakultas Hukum. Keseluruhan mahasiswa yang mengisi kuesioner menyatakan bahwa $100 \%$ telah melaksanakan pembelajaran daring di semester genap tahun akademik $2019 / 2020$.

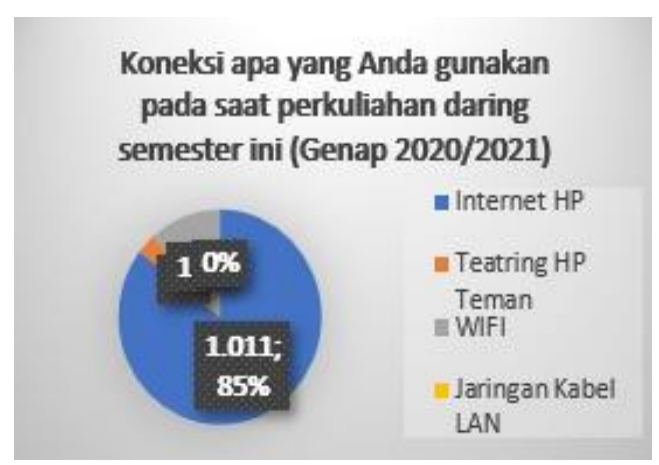

Gambar 2. Koneksi yang digunakan saat perkualiahan daring

Gambar di atas menunjukkan bahwa dari 1.204 mahasiswa lebih memilih koneksi yang digunakan untuk perkuliahan 
Available online at http://jurnal.goretanpena.com/index.php/JSSR

daring adalah internet HP sebanyak $1.011(85 \%)$ dikarenakan sinyalnya lebih bagus dibandingkan koneksi yang lain, seperti wifi, tethering HP teman, dan tidak ada yang menggunakan jaringan kabel LAN.

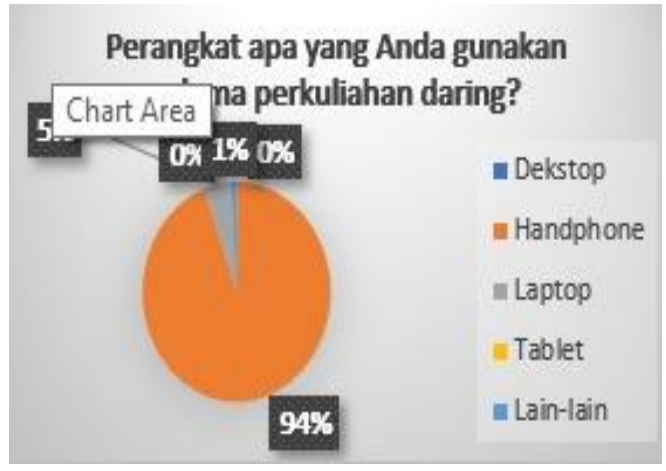

Gambar 3. Perangkat yang digunakan selama Perkuliahan daring

Perangkat yang digunakan selama perkuliahan daring adalah HP sebanyak 1.132 (94\%) mahasiswa dikarenakan bisa dibawa kemana-mana dan bersifat fleksibel dibandingkan perangkat yang lain yaitu laptop, desktop, tablet, dan lain-lain

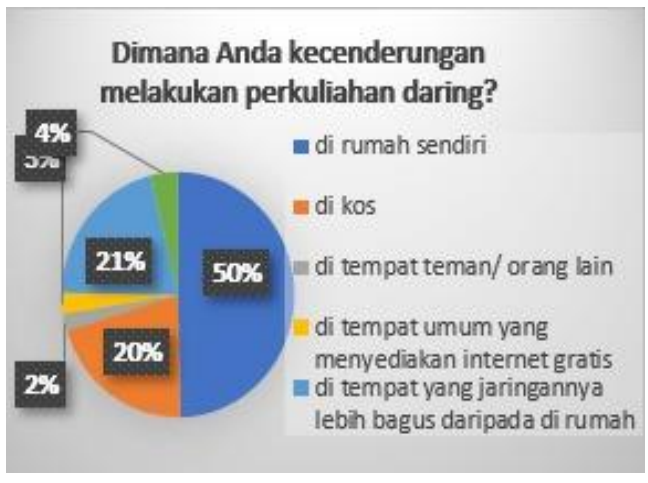

Gambar 4. Tempat melakukan perkuliahan

Mahasiswa lebih nyaman melakukan perkuliahan daring di rumah ditunjukkan dengan 598 (50\%), dibandingkan lokasi lain, karena rumah merupakan tempat paling nyaman dibandingkan yang lain, seperti di kos, ditempat teman/orang lain, ditempat umum yang menyediakan internet gratis, ditempat yang jaringannya lebih bagus daripada di rumah, dan lain-lain. Data ini juga menunjukkan mahasiswa lebih memilih pulang ke daerahnya masing-masing untuk menghemat biaya hidup di kota Bengkulu.
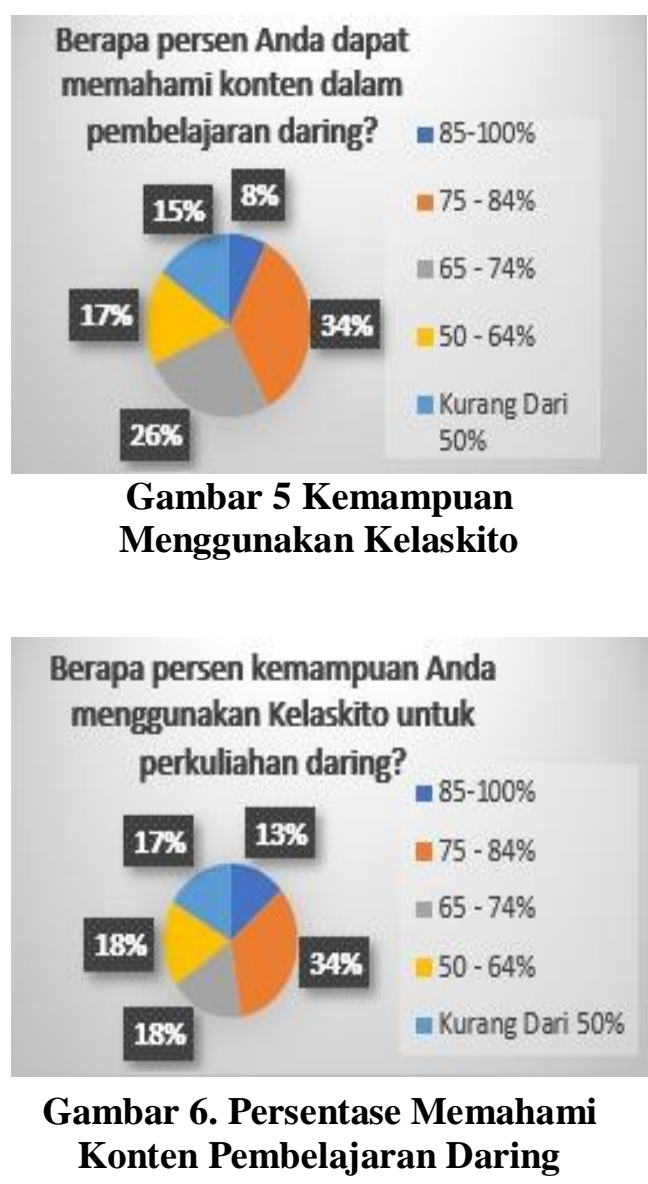

Dari 1.204 responden mengungkapkan bahwa 409 (34\%) mahasiswa memiliki kemampuan baik kisaran nilai antara 75 - 84\% dalam menggunakan kelas kito dalam perkuliahan daring. Hal ini mendukung program pemerintah dalam mengurangi penyebaran Covid 19. Hasil ini juga didukung jawaban berikutnya bahwa mahasiswa sangat memahami semua konten pembelajaran daring sebanyak 414 (34,4\%) mahasiswa baik berada di kisaran nilai $75-84 \%$. Ini menandakan bahwa generasi milineal yang melek terhadap IT. Akan tetapi, jika digabungkan antara persentase 75$84 \%$ dan $85-100 \%$ angkanya masih di bawah 50\%. Artinya, pemahaman mahasiswa cenderung cukup dan kurang. 
Available online at http://jurnal.goretanpena.com/index.php/JSSR

Apa platform/software/media yang digunakan dosen Anda ketika melakukan perkuliahan sinkronous? (Boleh memilih lebih dari satu) 1.204 jawaban

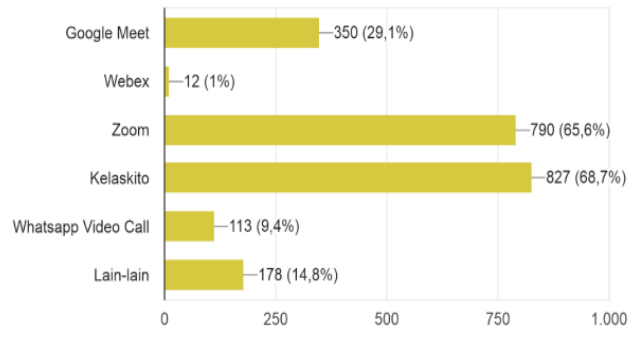

\section{Gambar 7. Platform/sofware/media yang digunakan dosen ketika melakukan perkuliahan sinkronous}

Berdasarkan gambar di atas menunjukkan bahwa platform/sofware/media yang digunakan dosen untuk pembelajaran sinkronoussangat beragam. Responden dapat memilih lebih dari 1 media online yang digunakan. Kelas kito menempati peringkat terbanyak pertama, yaitu $68,7 \%$, kemudian terbanyak kedua yaitu zoom yaitu $65,6 \%$, selanjutnya penggunaan googlemeet sebanyak $29,1 \%$, lalu menggunakan media lain, seperti Ms. Team sebanyak $14,8 \%$, whatsapp video call sebanyak $9,4 \%$ dan sisanya $1 \%$ menggunakan media webex.

Apa platform/software/media yang digunakan dosen Anda ketika melakukan perkuliahan asinkronous/ buk...online? (Bisa memilih lebih dari satu) 1.204 jawaban

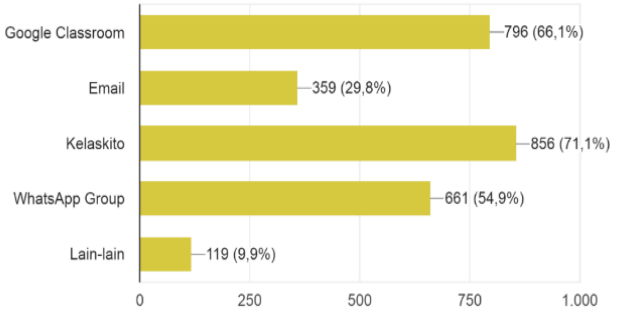

\section{Gambar 8. Platform/sofware/media yang digunakan dosen ketika melakukan perkuliahan asinkronous}

Berdasarkan gambar di atas menunjukkan bahwa platform/sofware/media yang digunakan dosen untuk pembelajaran asinkronoussangat beragam. Responden dapat memilih lebih dari 1 media online yang digunakan. Kelas kito menempati peringkat terbanyak pertama, yaitu $71,1 \%$, kemudian terbanyak kedua yaitu google classroom yaitu $66,1 \%$, selanjutnya penggunaan WhatsApp Group sebanyak 54,9\%, lalu email sebanyak $29,8 \%$ dan menggunakan media lainsebanyak $9,9 \% \%$.

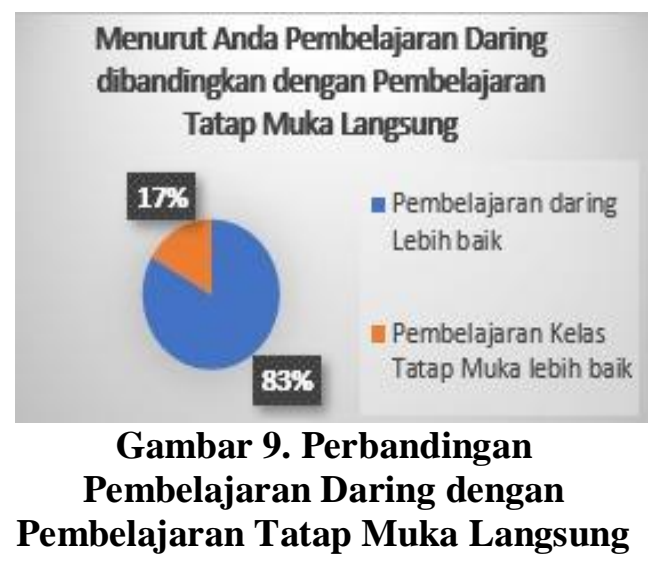

1.004 mahasiswa kecendrungan lebih memilih pembelajaran kelas tatap muka sebanyak $\quad 83,4 \%$ dibandingkan pembelajaran daring, hal ini didukung dari hasil survei kendala-kendala yang dihadapi selama perkuliahan daring.

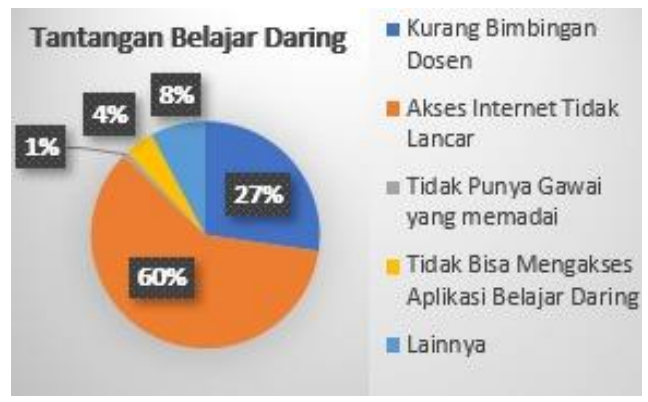

\section{Gambar 10. Tantangan Belajar Daring}

Pada item kuesioner berikutnya memperlihatkan bahwa mahasiswa lebih berminat belajar secara offline yaitu pembelajaran di kelas secara tatap muka dibandingkan dengan pembelajaran secara online di rumah. Hal ini berdasarkan data kuantitatif yang diperoleh bahwa 83\% memilih belajar di kelas (offline), dan sisanya $17 \%$ 
Available online at http://jurnal.goretanpena.com/index.php/JSSR

memilih belajar secara daring (online). Pernyataan $83 \%$ mahasiswa yang menyatakan lebih suka belajar di kelas secara tatap muka (offline) dikuatkan oleh pernyataan mahasiswa tentang hambatan yang alami selama pembelajaran daring (online) di rumah.

Sebanyak $60 \%$ menyatakan bahwa akses internet kurang lancar dikarenakan kebanyakan mahasiswa tinggal di daerah yang jauh dari sinyal internet. 27\% mahasiswa menyatakan bahwa bimbingan yang dilakukan oleh dosen kurang maksimal. 4\% mahasiswa menyatakan kesulitan dalam mengakses aplikasi belajar online. 8\% lainnya. 1\% mahasiswa menyatakan tidak mempunyai gawai yang memadai.Meskipun mayoritas mahasiswa lebih memilih belajar di rumah secara tatap muka (offline), tetapi mahasiswa tetap merasakan dampak positif dari pembelajaran daring. Sebanyak 40,3\% mahasiswa menyatakan kemudahan belajar di mana saja dan kapan saja, 22,6\% menyatakan lebih peka terhadap teknologi pembelajaran, $17,7 \%$ mahasiswa menyatakan bahwa gaya belajar dapat diatur sendiri, $9,7 \%$ mahasiswa merasakan efisiensi waktu, $8,1 \%$ mahasiswa bisa belajar lebih tenang dan fokus, dan 1,6\% menyatakan semua dampak positif dari pembelajaran daring dirasakan oleh mahasiswa.

Hal ini memperlihatkan bahwa seluruh dosen dan mahasiswa mengikuti kebijakan dari Pemerintah pada umumnya dan kebijakan dari Universitas pada khususnya yang menetapkan bahwa selama pandemi Covid 19, pembelajaran dilakukan secara daring atau online. Surat Edaran Mendikbud Nomor: 36962/MPK.A/HK/2020 tentang "Pembelajaran secara Daring dan Bekerja dari Rumah dalam rangka Pencegahan Penyebaran Corona Virus Disease (Covid- 19)" telah dilaksanakan dengan baik oleh dosen dan mahasiswa di Universitas Muhammadiyah Bengkulu.

Hasil survei diperoleh informasi bahwa pembelajaran daring yang dilakukan menggunakan media online yang beragam. Terdapat 4 media online /daring baik sinkronous dan asinkronous dengan penggunaan di atas $60 \%$ yaitu Kelas Kito $(68,7 \%)$, Zoom $(65,6 \%)$, google classroom $(66,1 \%)$. Hal ini memperlihatkan bahwa dosen menggunakan media online yang bervariasi. Seperti temuan penelitian Shenoy yang menunjukkan bahwa selama periode lockdown, Sekolah Bisnis ISBR Bangalore telah menjalani proses adopsi teknologi dan mahasiswa terlibat dengan berbagai model pembelajaran online (Shenoy, Mahendra, \& Vijay, 2020). Pembelajaran daring dapat meningkatkan interaksi pada proses pembelajaran, dapat mengakses dan berkomunikasi dengan teman sekelas serta pengajarnya (Maskar \& Wulantina, 2019; Liu, H.-C., \& Chuang, 2016).

Meskipun pembelajaran daring yang dilaksanakan selama pandemi Covid-19 tetap dilaksanakan pada semester genap Tahun Akademik 2019/2020 di Universitas Muhammadiyah Bengkulu, namun mahasiswa lebih menyukai pembelajaran secara tatap muka (offline) di kelas. Mahasiswa menyatakan pembelajaran secara daring mengharuskan mahasiswa untuk aktif internet dengan membeli kuota internet lebih sering. Hal ini mengakibatkan pengeluaran semakin meningkat. Belum lagi jika mahasiswa yang berasal dari beberapa daerah terpencil yang sulit untuk memperoleh jaringan internet yang lancar. Kendala ini menjadi kendala paling sering ditemui pada pembelajaran daring. Sejalan dengan penelitian Mulyana dkk. (2020), mengungkapkan bahwa kendala mengikuti perkuliahan daring muncul oleh karena ketersediaan kuota akses internet yang tidak selalu ada. 
Available online at http://jurnal.goretanpena.com/index.php/JSSR

Ketersediaan kuota akses internet ini tidak selaras dengan adanya dukungan keluarga kepada mahasiswa untuk selalu mengikuti perkuliahan daring. Keterbatasan kuota akses internet dipengaruhi oleh kesiapan sumberdaya yang dimiliki keluarga untuk para mahasiswa. Tidak sedikit para mahasiswa yang harus berhemat dalam penggunaan kuota akses internet. Mereka harus berbagi dengan pemenuhan kebutuhan sehari-hari yang lainnya.

Salah satu penyebab keterbatasan sumberdaya ini, adalah kondisi yang memaksa orang tuanya atau mahasiswa yang bersangkutan tidak bekerja saat wabah Covid-19, sehingga tidak memiliki penghasilan, kurangnya tingkat pengetahuan dan keterampilan siswa dalam penggunaan e-learning serta kurangnya akses ke perangkat dan koneksi (Mailizar dkk., 2020). Demuyakor (2020), mengungkapkan bahwa siswa di luar China karena Covid-19 terjadinya pemborosan dalam pembelian data internet untuk pembelajaran online dan konektivitas internet sangat lemah jika meninggalkan asrama berbagai universitas di Cina.

\section{SIMPULAN}

Pandemik covid-19 memberikan dampak negatif pada pembelajaran. Sebagai akibat dari pandemik tersebut yaitu berubahnya sistem pembelajaran luring menjadi sistem pembelajaran daring. Pembelajaran daring tersebut, tidak efektif membantu mahasiswa dalam belajar. Mahasiswa dan dosen selama ini juga tidak terbiasa dalam melaksanakan pembelajaran secara daring. Mahasiswa cenderung kesulitan dalam memahami konsep dari sumber belajar yang disediakan oleh dosen. Kurangnya keterampilan menggunakan platform aplikasi pembelajaran daring dan juga tidak meratanya akses internet di berbagai daerah juga menjadi penghambat tersendiri bagi proses pembelajaran daring. Dengan demikian, pelatihan teknis dalam menggunakan berbagai macam platform aplikasi pembelajaran daring bagi mahasiswa dan dosen, dan pelatihan strategi pembelajaran daring bagi dosen dapat menjadi solusi terhadap berbagai temuan penelitian ini. Peran aktif pemerintah dalam pengadaan fasilitas internet juga diharapkan dapat mengatasi kesulitan akses internet di berbagai daerah.

\section{UCAPAN TERIMA KASIH}

Dengan terselesaikan artikel hasil penelitian ini, penulis mengucapkan terimakasih kepada LPMPP Universitas Muhammadiyah Bengkulu atas support dan motivasi yang telah diberikan sehingga peneliti dapat melaksanakan penelitian dari tahap awal hingga penyusunan artikel hasil penelitian ini. Pak Imanullah, M.T. dan Dr. Imam Syafi'i, M.Pd. yang telah menyempatkan untuk memberikan masukan.

\section{DAFTAR PUSTAKA}

Akkoyunlu, B., \& Yilmaz-Soylu, M. (2008). Development of a scale on learners' views on blended learning and its implementation process. Internet and Higher Education, 11(1), 26-32. https://doi.org/10.1016/j.iheduc.2 007.12 .006

Bonk, C. J., \& Kim, K. (2004). Future Directions Of Blended Learning In Higher Education And Workplace Learning Settings.

Cheung, K. S., Lam, J., Lau, N., \& Shim, C. (2010). Instructional design practices for blended learning. 2010 International Conference on Computational Intelligence and Software Engineering, CiSE 2010, 0-3. https://doi.org/10.1109/CISE.201 0.5676762

Demuyakor, J. (2020). Coronavirus (Covid-19) and Online Learning in Higher Institutions of Education: A Survey of The 
Available online at http://jurnal.goretanpena.com/index.php/JSSR

Perceptions of Ghanaian International Students in China. Online Journal of Communication and Media Technologies, 10(3), e202018.

https://doi.org/10.29333/ojcmt/82 86

Hilliard, A. T. (2015). Global Blended Learning Practices For Teaching And Learning, Leadership And. Journal of International Education Research, 11(3), 179-188

Kintu, M. J., Zhu, C., \& Kagambe, E. (2017). Blended learning effectiveness: the relationship between student characteristics, design features and outcomes. International Journal of Educational Technology in Higher Education, 14(1). https://doi.org/10.1186/s41239017-0043-4

Liu, H.-C., \& Chuang, H.-H. (2016). Integrating Google Classroom to Teach Writing in Taiwan. Minnesota eLearning Summit.

Mailizar, Almanthari, A., Maulina, S., \& Bruce, S. (2020). Secondary School Mathematics Teachers' Views on E-learning Implementation Barriers During the Covid-19 pandemic: The Case of Indonesia. Eurasia Journal of Mathematics, Science and Technology Education, 16(7). https://doi.org/10.29333/EJMSTE 18240

Maskar, S., \& Wulantina, E. (2019). Persepsi Peserta Didik terhadap Metode Blended Learning dengan Google Classroom. Jurnal Inovasi Matematika, 1(2), 110-121. https://doi.org/10.35438/inomatik a.v1i2.156

Mulyana, M., Rainanto, B. H., Astrini, D., \& Puspitasari, R. (2020). Persepsi Mahasiswa Atas Penggunaan Aplikasi Perkuliahan Daring Saat Wabah Covid-19. JAS-PT (Jurnal Analisis Sistem
Pendidikan Tinggi Indonesia), 4(1), 47. https://doi.org/10.36339/jaspt.v4i 1.301

Porter, W. W., Graham, C. R., Spring, K. A., \& Welch, K. R. (2014). Blended learning in higher education: Institutional adoption and implementation. Computers and Education, 75, 185- 195. https://doi.org/10.1016/j.compedu .2014.02.011

Septiana, Yolandari. (2020). Persepsi Mahasiswa Tentang Implementasi Blended Learning pada Mata Kuliah Strategi Pembelajaran Akuntansi. Business and Accounting Education Journal, 1(3), 213-221

Shenoy, V., Mahendra, S., \& Vijay, N. (2020). Covid-19 Lockdown Technology Adaption, Teaching, Learning, Students Engagement and Faculty Experience. Mukt Shabd Journal, 9(4), 698-702. Retrieved from https://www.researchgate.net/publ ication/34060 9688

Stockwell, B. R., Stockwell, M. S., Cennamo, M., \& Jiang, E. (2015). Blended Learning Improves Science Education. Cell, 162(5), 933-936. https://doi.org/10.1016/j.cell.2015 .08 .009 